\title{
14. Debt management capacity: a tale of three Asias
}

\author{
Phillip Anderson ${ }^{1}$
}

\section{INTRODUCTION}

Over the last two decades, many Asian economies have sought to build their capacity to manage public debt and develop their domestic debt markets. Several economies rose to this challenge early and now have debt management operations that are among the best in the world and deeper and more liquid bond markets. Less-developed economies at the earlier stages are facing hurdles arising from lack of scale, conflict, or prolonged low-income status. At the same time, the financing choices available to government have increased as international capital markets and official sector lending continue evolving. Governments must manage efforts to address the challenges amid higher public debt levels and the economic impact of the COVID-19 pandemic.

This chapter identifies areas where more capacity-building effort is needed to manage public debt and develop the domestic debt markets. But developments in public financial and fiscal risk management also have implications for a government's debt management capacity. Central government debt is a major component in the identification and compilation of the public sector balance sheet. To manage risks across this broader canvas, the government could draw on already existing skills in the public debt management function, although the institutional hurdles are significant. In addition, market instruments can be used to manage fiscal risks and pressures, as discussed in other chapters. Again, the debt management function could contribute, given its role of analyzing risk and transacting in markets.

\section{DEFINING AND MEASURING DEBT MANAGEMENT CAPACITY}

Public debt management involves the composition of public debt, while debt sustainability focuses on identifying sustainable levels of debt in the long run. Despite their distinct objectives, both are of course closely related. The International Monetary Fund (IMF) and the World Bank (2014) cite numerous examples of economies with poorly structured debt in terms of currency, maturity, or interest-rate composition, which induced or exacerbated liquidity and sustainability crises. A number of these events occurred in the 1990s and focused global attention on how economies manage public debt. As a result, when asked to develop guidance on what constitutes sound practice, the IMF and the World Bank published the "Guidelines for Public Debt Management" in 2001 and a revision in 2014. ${ }^{2}$ 
The Asian financial crisis, which afflicted several economies in East Asia during 1997-1998, did not directly implicate government debt, but highlighted vulnerabilities in financial systems that relied excessively on bank financing and leverage. Governments saw the necessity to focus on the development of domestic bond markets to increase resilience and improve capital allocation. To help economies achieve this objective, the Association of Southeast Asian Nations (ASEAN), the People's Republic of China (PRC), Japan, and the Republic of Korea (ROK) launched the Asian Bond Markets Initiative in 2002, with the Asian Development Bank (ADB) serving as secretariat and providing technical support.

To manage central government debt effectively, an institution must establish objectives, develop and implement strategies, and maintain the highest levels of accountability and transparency. While the main focus is on the entity or entities that are directly responsible for borrowing on behalf of the central government, other policy areas contribute to strengthening debt management capacity. In particular, the institutional capacity to implement fiscal policy, cash management, monetary policy, and capital market regulation influences public debt management outcomes. The development of the local financial market and the quality of its infrastructure also play a role.

The Guidelines for Public Debt Management were a useful step in codifying what experienced practitioners viewed as the necessary framework for the activity. Experience in applying this guidance in many economies led to the development of a tool to assess capacity through performance indicators, the Debt Management Performance Assessment (DeMPA) methodology (Box 14.1). ${ }^{3}$

\section{BOX 14.1 DEBT MANAGEMENT PERFORMANCE ASSESSMENT METHODOLOGY}

The World Bank in 2009 developed the Debt Management Performance Assessment (DeMPA) methodology to assess the institutional performance of developing economies through a comprehensive set of indicators spanning the full range of government debt management functions. Modeled after the Public Expenditure and Financial Accountability indicators, the assessment scores performance at four levels. There are 14 indicators grouped in five areas:

1. Governance and Strategy Development: five indicators, covering legal framework, management structure, debt management strategy, debt reporting and evaluation, and audit.

2. Coordination with Macroeconomic Policies: two indicators, covering coordination with fiscal policy, and with monetary policy.

3. Borrowing and Related Financing Activities: three indicators, for domestic borrowing, external borrowing, and loan guarantees, onlending and derivatives.

4. Cash Flow Forecasting and Cash Balance Management: one indicator.

5. Debt Recording and Operational Risk Management: three indicators covering debt administration and data security; segregation of duties, staff capacity and business continuity; and debt and debt-related records.

Source: World Bank (2015). 
While the DeMPA is designed to apply to developing and emerging market economies, it has been used largely in low-income economies and lower-middle-income economies. While most economies choose not to publish DeMPA reports, the World Bank has compiled aggregate data to show the pattern of strengths and weaknesses across indicators and their progress through time. Figure 14.1 shows a recent analysis measuring progress in 37 economies that had performed two DeMPA assessments from 2008 to 2015 (World Bank and the IMF 2018). The data show the number of economies that had an adequate level of performance (i.e. a score of $\mathrm{C}$ or better) for each of the 14 indicators and the results are mixed, with an improvement in some areas and a deterioration in others. Overall, the results highlight the challenges faced by low-income economies and lower-middle-income economies: on average, these economies had a satisfactory score for only around 30 percent of the indicators.

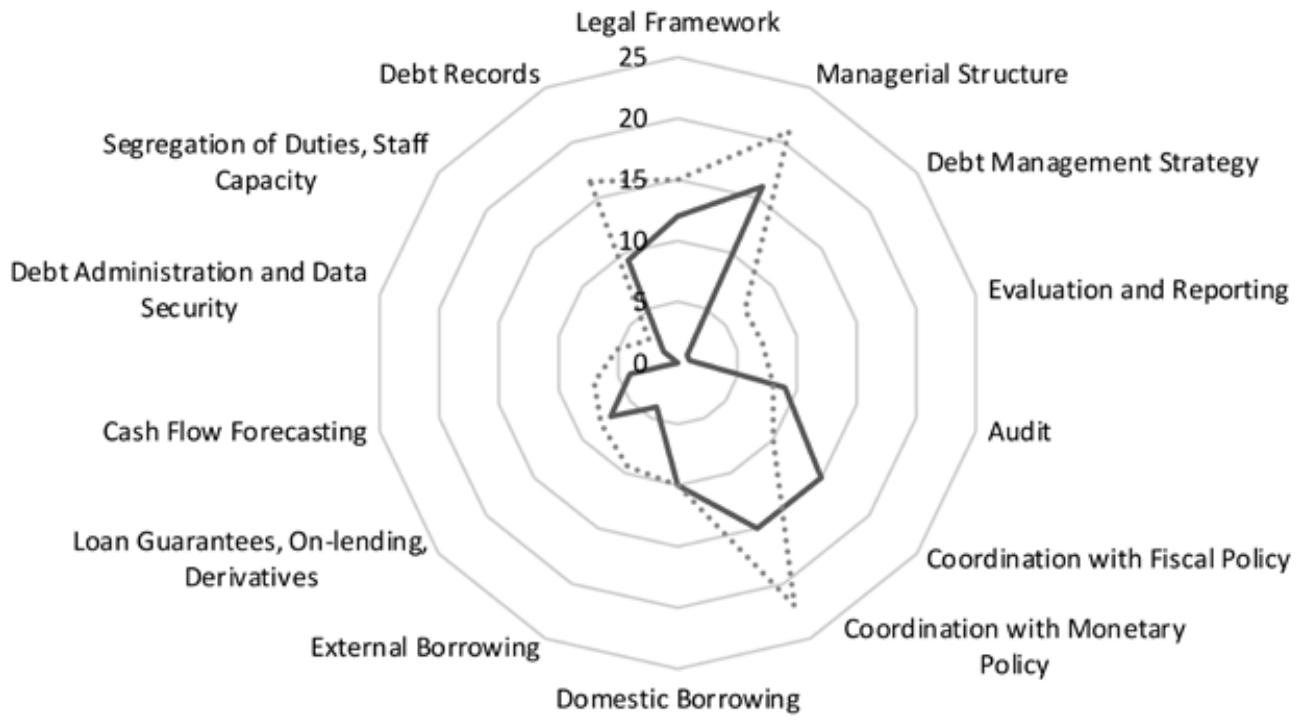

1st DeMPA $\cdots \cdot \cdot$ 2nd DeMPA

Note: DeMPA = debt management performance assessment.

Source: World Bank and IMF (2018).

Figure 14.1 Changes in DeMPA scores for 37 low-income economies and lower-middle-income economies

The analysis does not provide a geographic breakdown, so it is not possible to obtain a picture for "developing Asia" as classified by ADB. Nevertheless, 21 economies have had a DeMPA and, of these, seven have published results (World Bank 2020). 


\subsection{Debt Management Capacity in Developing Asia}

A challenge in reviewing the debt management capacity across ADB's 46 developing Asian economies is their diversity. For example, they range in population from 1,600 in Niue to over 1,400 million in the PRC. The group includes nine economies classified by the World Bank as "fragile and conflict-affected states" (FCS) but also lists Singapore and Brunei Darussalam, which are among the top 10 economies ranked by gross domestic product (GDP) per capita, and with Hong Kong, China not far behind. Also, the level of public debt ranges from 3 percent to over 100 percent of GDP, with 10 economies viewed by the IMF and the World Bank at high risk of debt distress.

To meaningfully consider the challenges for institutional capacity to manage public debt, we separate developing Asia into three groups:

- Group 1: Economies that have no or very little domestic debt and rely on official sources of financing (most of the Pacific island economies and a few others); borrowing choices are limited and volumes are tightly constrained by sustainability concerns.

- Group 2: Economies that rely largely on the domestic market (90 percent or more), including the high-income economies, the PRC, India, Malaysia, and Thailand. Debt portfolios have little currency risk and weight is placed on developing and improving the local bond market. This group has institutional requirements similar to most Organisation for Economic Co-operation and Development (OECD) economies (although they may have residual official debt and some international bonds).

- Group 3: The group in the middle comprises economies with the broadest range of financing sources (bilateral, multilateral, possibly international bonds, and domestic market). Their level of domestic market development is wide-ranging, from nascent to mature.

We develop an overview of debt management capacity in each of these groups using several sources such as full DeMPA reports, summary DeMPA scores published in World Bank (2020), other published works, disclosure on member government websites, and the functioning of domestic debt markets.

\subsection{Group 1 (With Official Sources of Financing, Little Domestic Debt)}

This group comprises 13 economies, including most of the small Pacific island economies and other developing Asian economies such as Bhutan and Cambodia. Under the World Bank's Debt Sustainability Framework as of the end of 2019, five economies have been assessed as high risk of external debt distress and four are classified as FCS (World Bank 2020).

Most of these economies have no domestic debt, while those that do have less than 5 percent of total public debt. For the larger economies, this reflects their stage of economic and financial sector development; for the small island states, the lack of scale represents a challenge in developing a securities market. Institutional capacity in the near term is therefore shaped with financing from official sources and includes selecting the most beneficial and cost-effective loans within a sustainable fiscal envelope, which in many cases is already stretched. Effective debt administration must ensure accurate and timely recording and reporting of obligations. Although the loans are granted on either concessional or below-market terms, they are denominated in foreign currency, exposing the public debt portfolio to significant currency risk. 
There is some evidence that small states generally have lower debt management capacity than larger economies. Prasad et al. (2013) analyzed 17 DeMPA reports for small states and compared them with a sample of 42 larger economies with similar income and debt levels. ${ }^{4}$ The study found that in aggregate the small states met the minimum requirement for 32 percent of the dimensions assessed, whereas the larger economies achieved 41 percent on average. One counterintuitive finding is that there was no correlation between gross national income (GNI) per capita and institutional performance for the small states in this sample. Nevertheless, the study found that the small states had limited staff numbers with broad spans of responsibility and little or no reserve capacity, which may have a bearing on the scores that were observed.

These challenges appear to be evident in the small Pacific island economies. The Pacific Association of Supreme Audit Institutions (PASAI 2016) summarizes patterns of weakness in capacity, based on the findings of the supreme audit institutions (SAIs) in eight Pacific island territories and economies. In the area of governance, four of the eight SAIs highlighted problems such as the lack of a legal framework, absence of a strategy, weak organizational structure, and weak internal controls and procedures. The weakest area was in monitoring and reporting, with six of the eight SAIs finding a lack of available information or documentation, which casts doubts on the accuracy and completeness of the government's financial reports. Contributing factors could be suboptimal use of debt management software as well as irregular reporting. In addition, the Pacific economies face unique development challenges arising from "extreme geography" (see Chapter 5 in this volume), which perennially threaten debt sustainability.

Of the two larger economies that have had DeMPAs, Afghanistan scored a 40 percent satisfactory rate in 2011, despite being an FCS at high risk of debt distress. ${ }^{5}$ Cambodia rated 30 percent in 2018, around the global average indicated in Figure 14.1, and has published a debt management strategy and regular bulletins on the composition of public debt on the finance ministry website. Bhutan scored satisfactory on 40 percent of indicators - better than the small-country average (World Bank 2020).

Eight of the economies in Group 1 have made improvements to debt management capability in recent years, such as new legislation, better debt recording systems, preparation of debt management strategies, or publication of public debt reports. ${ }^{6}$ Nevertheless, challenges remain - for example, only five of the 13 economies publish debt data regularly on websites, and only 3 have published a debt management strategy.

\subsection{Group 2 (Domestic Market Borrowing is at Least 90 percent of Public Debt)}

There are nine economies in this group: Brunei Darussalam; Hong Kong, China; India; Malaysia; the PRC; the ROK; Singapore; Taipei,China; and Thailand. The high-income economies (Brunei Darussalam; Hong Kong, China; the ROK; Singapore; and Taipei,China) borrow only in the domestic market in local currency, while the PRC, Malaysia, and Thailand have some residual foreign-currency debt (less than 3 percent of total public debt). Although India has, in absolute terms, sizable official borrowing denominated in foreign currencies, it amounts to less than 7 percent of total public debt.

To manage public debt, these economies focus on the management of refinancing and interest-rate risk and on developing the domestic securities market. Brunei Darussalam and Hong Kong, China have very little public debt, at less than 3 percent of GDP, so risks are 
minimal in any event. The other economies issue securities across the yield curve, with tenors extending to at least 30 years. The PRC, Thailand, and the ROK have issued 50-year bonds. In this context, debt managers have sufficient choices in instruments to keep risks in check in line with their objectives.

All of the economies in this group have over a long period developed their domestic government securities markets, some starting from the early 1990s. With the exception of India and Taipei,China, they participate in the Asian Bond Markets Initiative (ABMI), which was launched in December 2002 to develop local currency bond markets and promote regional financial cooperation. ${ }^{7}$ ABMI was established in the aftermath of the Asian financial crisis, which was caused largely by "balance sheet mismatches" in the private sector-businesses had borrowed through short-term bank loans in foreign currency to finance long-term investments that generated returns in domestic currency (ADB 2019). While the objective was to develop local currency debt capital markets for the private sector, the government securities market usually comes first in developing and emerging market economies and acts as a benchmark.

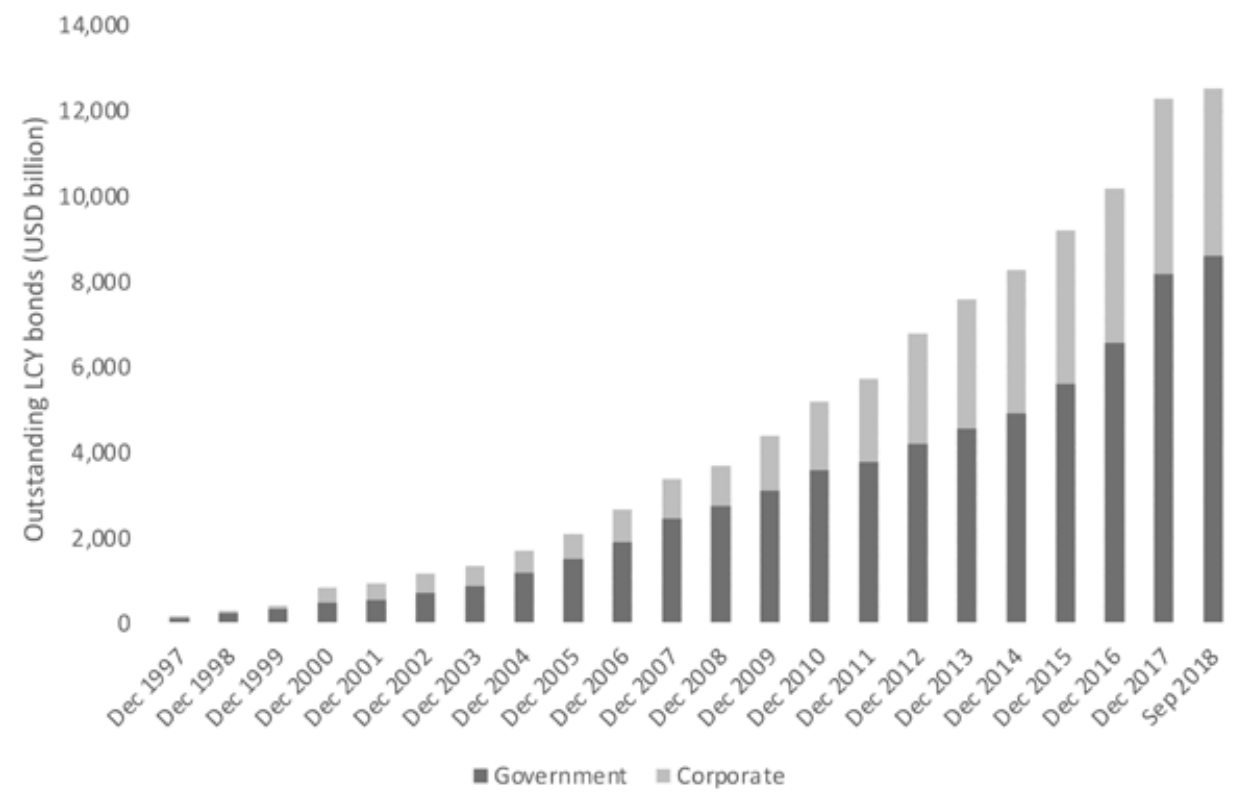

Notes:

LCY $=$ local currency.

Economies include Indonesia; Malaysia; Singapore; Thailand; the Philippines; the PRC; Hong Kong, China; the ROK; and Viet Nam.

Source: ADB (2019).

Figure 14.2 Growth of emerging East Asian local currency bond markets, 1997-2018

The analysis undertaken as part of the ABMI shows that each economy had a unique approach in developing its market, which is consistent with development pathways in other economies. 
Nevertheless, we identified some commonalities. During the initial phase (2002-2007), governments focused on increasing the supply of local currency securities, developing market infrastructure, improving access for investors, strengthening regulation, and improving access for a range of issuers (ADB 2017). Subsequently, initiatives to expand regional integration and deepen the private sector bonds markets complemented these efforts. ${ }^{8}$ Figure 14.2 shows the impressive growth in the volume of bonds outstanding.

Singapore and Hong Kong, China issue government securities to support the development and functioning of local markets, even though there is no fiscal need to borrow. In Hong Kong, China, government securities amount to around 3 percent of GDP, while the fiscal reserve is around 40 percent of GDP. Under Singapore's Government Securities Act, the proceeds from issuance cannot be spent for budgetary purposes and are invested. The principal objectives of securities issuance are to provide a robust yield curve and fostering the growth of an active secondary market.

The successful development of an economy's local market is measured in part by its liquidity, one indicator of which is the difference between the yields at which bonds are bought and sold (the bid-ask spread). The size of the bond market also contributes to its liquidity-even the most efficient small market will have less liquidity than a large one. Nevertheless, the changes each market goes through over time provide an indication of structural improvements. Table 14.1 shows the improvement in selected economies since 2004.

Table 14.1 Selected economies: government bonds bid-ask spreads (basis points)

\begin{tabular}{|c|c|c|c|c|c|c|c|c|c|c|c|}
\hline Market & 2004 & $\ldots$ & 2010 & 2011 & 2012 & 2013 & 2014 & 2015 & 2016 & 2017 & 2018 \\
\hline People's & 32.5 & & 2.2 & 4 & 2.7 & 4.1 & 3.4 & 5.3 & 1 & 1 & 1.9 \\
\hline \multirow{2}{*}{\multicolumn{12}{|c|}{$\begin{array}{l}\text { Republic of } \\
\text { China }\end{array}$}} \\
\hline & & & & & & & & & & & \\
\hline Republic of & 4.8 & & 1.1 & 0.7 & 0.6 & 0.7 & 0.7 & 0.5 & 0.5 & 0.5 & 0.5 \\
\hline \multicolumn{12}{|l|}{ Korea } \\
\hline Malaysia & 3.5 & & 2.6 & 3.3 & 2.7 & 3.8 & 1.7 & 2.4 & 2.1 & 1.9 & 2.3 \\
\hline Singapore & 5.5 & & 3 & 3.8 & 3.1 & 2.6 & 2.3 & 2 & 3 & 3 & 2.1 \\
\hline Thailand & 7.3 & & 3.1 & 3.3 & 3.2 & 2.4 & 1.9 & 1.5 & 2.3 & 1.8 & 2.5 \\
\hline
\end{tabular}

Source: ADB (2019).

The development of local currency government bond markets is a complex process and requires that public institutions have a deep understanding of financial markets. As the issuer, the government controls all aspects of the primary market, including the issuance methods, choice of instruments, and rules for market access. The choices made will have a significant impact on the efficiency of the secondary market. In addition, extensive collaboration with the regulator, the central bank, and market participants is essential to develop other dimensions of market liquidity. The economies in this group have adopted a range of approaches: India; Hong Kong, China; Malaysia; and Singapore have relied extensively on the monetary authorities as agents to build their markets. ${ }^{9}$ Thailand established its Public Debt Management Office in 1999 as an agency of the government to manage all aspects of public debt. In the PRC and the ROK, the finance ministry is given the responsibility for the daily management of public debt. 


\subsection{Group 3 (A Range of Financing Sources)}

The remaining economies in developing Asia (24) are grouped together, but reflect a wide range in levels of institutional capacity. One common aspect across the group is their access to a broad range of financing sources, including official sources, domestic markets, and the international capital markets, although the mix of these sources varies a great deal. Some economies are advanced in developing the domestic securities market and have been relying on it for over 60 percent of financing (Indonesia and the Philippines), whereas others are only beginning the process (Armenia and the Lao People's Democratic Republic (Lao PDR)). Of the 24 economies, 15 have issued international sovereign bonds at least once, while some are regular issuers (Indonesia and the Philippines).

Given the range of financing alternatives, the economies in this group have more complex trade-offs to make than the other two groups when developing their debt management strategies. They must consider the relative cost and risk of borrowing in foreign currencies, both from official and market sources, as well as the pace at which the domestic market can be developed as a source of longer-tenor financing. Also, they must maintain the institutional capacity to tap each source of financing.

Most of the eight economies in Central Asia could be regarded as having strong debt management capacity. ${ }^{10}$ Five have had DeMPAs, of which three (Armenia, Georgia, and Kazakhstan) have been published and show considerably higher scores on average than the global sample illustrated in Figure 14.1, scoring satisfactory for 50-75 percent of indicators. The summary data for the Kyrgyz Republic and Tajikistan are not as strong-around 40 percent satisfactory - but are still favorable compared with global averages. Since the assessments, these economies have made improvements to debt management practices such as greater transparency, development of strategies, market development initiatives, and updates of the legal framework (World Bank 2020).

Six of the eight economies have issued international bonds, with Uzbekistan joining the group with its first issue in 2019. Resource-rich Azerbaijan and Kazakhstan with their substantial financial assets have relatively low levels of public debt - at just over 20 percent of GDP at the end of 2019-but recognize the value of a government bond market for financial sector development. Both are active in pursuing initiatives to this end, but development is still at an early stage, with Azerbaijan having a very low level of securities outstanding and Kazakhstan's investor base heavily concentrated. Similarly, domestic government debt in Armenia, Georgia, the Kyrgyz Republic, and Tajikistan is less than 20 percent of total public debt. Uzbekistan began issuing domestic securities in December 2018, and the authorities have committed to developing this market (IMF and the World Bank 2019).

Overall, the Central Asian economies rate well in transparency, with six economies providing statistical bulletins or debt data on websites regularly. Five economies publish their public debt management strategies and, with three published DeMPAs, they are more open than the other regions. The pattern of strong capacity is likely to be related to income-five economies are classified as upper-middle income.

The five South Asian economies in this group - Bangladesh, Maldives, Nepal, Pakistan, and Sri Lanka - have a sizable proportion of public debt sourced in the domestic market, ranging from 45 percent to 65 percent. Maldives, Pakistan, and Sri Lanka have issued securities in the international capital markets and borrow extensively from official sources. Their debt levels 
are over 75 percent of GDP (as at the end of 2019), which is a major challenge for fiscal policy, with debt interest cost consuming much of the budget, indicating they must make cost-risk trade-offs when developing their debt management strategy.

All economies have had DeMPAs over the last decade and the summary results are not strong, ranging from less than 20 percent of indicators scoring satisfactory to around 35 percent. Maldives was the weakest, which may be an indication of challenges similar to those faced by small Pacific island states (World Bank 2019). Most have made improvements to debt management capacity in recent years, so it is plausible that the assessments understate current performance in some cases - for example, the Pakistan assessment is 10 years old (World Bank 2020).

In South Asian economies, the responsibility for managing public debt is dispersed across various entities. The central bank manages borrowing in the domestic market, in some cases with a high degree of discretion and not strictly as an agent. The finance ministry looks after external borrowing from official sources, while a team assembled for each operation oversees borrowing from the international capital markets. While guidance on international sound practices, including the DeMPA methodology, does not insist on a consolidated debt management office, it does reduce the risk of uncoordinated central government borrowing and expedites the logistics involved in developing and obtaining approval for an overall debt management strategy. Maldives and Nepal have plans to consolidate debt management activities, but they have not been fully carried out. Pakistan put in place a Debt Policy Coordination Office to coordinate the five separate units that manage parts of the public debt portfolio, but in March 2020 it announced a plan to consolidate the units into one debt office. Sri Lanka also has several times made plans to set up a single debt office but has yet to put them in place.

The level of transparency across economies is mixed. Maldives has since 2018 produced a regular, comprehensive bulletin on public debt, while the central banks of Sri Lanka and Pakistan provide some data in monthly or quarterly statistical releases. All economies except for Nepal have published a debt management strategy, although Bangladesh produced its strategy in 2014 and Sri Lanka its first in 2019 by setting up a working group.

The only country from East Asia in Group 3 is Mongolia, which was assessed in a 2016 DeMPA as having strong debt management capacity relative to global averages, with around 55 percent of indicators scoring satisfactory (World Bank 2020). And authorities have continued to make improvements since then. Between 2011 and 2016, the country's public debt escalated from around 35 percent of GDP to almost 90 percent, mostly through borrowing in the international capital markets, which led to a debt crisis and support being received from an IMF program and from other partners. By the end of 2019, debt levels had retreated to just over 70 percent of GDP. This debt matures between 2021 and 2024, so the portfolio has high levels of refinancing and interest-rate risk, in addition to currency risk. Domestic debt is negligible, at around 7 percent of total public debt.

Institutional capacity in the five Southeast Asian economies in this group is wide-ranging: Indonesia and the Philippines have strong and seasoned debt management operations, with Viet Nam not far behind, and Myanmar and the Lao PDR still at an earlier stage. ${ }^{11}$ Viet Nam is the only country that has available DeMPA information, which was assessed satisfactory for almost 50 percent of indicators in 2011, a strong score compared with global averages. Since then, it has implemented various initiatives including a revised law, published debt bulletins, and measures to improve the functioning of the domestic debt market (World Bank 2020). 
All economies participate in the ABMI, but by 2020 a meaningful secondary market has emerged only in Indonesia, the Philippines, and Viet Nam. Domestic market borrowing accounts for 60-65 percent of the public debt portfolios in these three economies. Much like the Group 2 economies, the bid-ask spread in the secondary market is a useful indicator of improvements in market efficiency over time. While market liquidity is assessed as lower than the Group 2 economies (Table 14.1), it has improved since 2004 or from when data became first available (Table 14.2).

Table 14.2 Government bonds bid-ask spreads, selected economies (basis points)

\begin{tabular}{lcrrrrrrrrrr}
\hline Market & $\mathbf{2 0 0 4}$ & $\mathbf{\ldots}$ & $\mathbf{2 0 1 0}$ & $\mathbf{2 0 1 1}$ & $\mathbf{2 0 1 2}$ & $\mathbf{2 0 1 3}$ & $\mathbf{2 0 1 4}$ & $\mathbf{2 0 1 5}$ & $\mathbf{2 0 1 6}$ & $\mathbf{2 0 1 7}$ & $\mathbf{2 0 1 8}$ \\
\hline Indonesia & 21.4 & & 4.8 & 5.0 & 5.9 & 7.6 & 6.0 & 9.2 & 5.2 & 3.3 & 5.3 \\
Philippines & 25.0 & & 3.1 & 5.3 & 2.1 & 5.4 & 3.3 & 3.4 & 4.6 & 3.7 & 6.9 \\
Viet Nam & n.a. & & 13.2 & 33.5 & 30.5 & 21.7 & 11.7 & 15.0 & 7.2 & 5.0 & 8.3 \\
\hline
\end{tabular}

Note: n.a. $=$ not applicable.

Source: ADB (2019).

Myanmar has been developing its domestic debt market since 2015, and regularly issues Treasury bills and Treasury bonds with maturities of up to five years. The bonds are concentrated into "benchmark" lines by reopening them at successive auctions. Transparency has improved in recent years, with an annual debt report presented to the legislature, and debt management strategies published on the finance ministry website. In the Lao PDR, domestic issuance is limited to Treasury bills by 2020 .

All Southeast Asia economies in this group issue in the international capital markets, with the exception of Myanmar. Indonesia and the Philippines have the scale to issue benchmark bonds, with volumes of well over $\$ 1$ billion. In addition, Indonesia is one of a few emerging market sovereigns to issue in the international green bond market, which it has tapped three times since 2018. The Lao PDR has borrowed in the baht and United States dollar markets.

This group includes four economies from the Pacific: Fiji, Papua New Guinea (PNG), Solomon Islands, and Vanuatu. PNG, Solomon Islands, and Vanuatu have had DeMPAs undertaken during 2015 to 2020 with summary scores indicating fairly weak capacity in Solomon Islands and Vanuatu, consistent with the scores of other small island nations. PNG scored a little stronger than the global averages (Figure 14.1). Fiji, Vanuatu, and Solomon Islands regularly publish data on public debt. Fiji, PNG, and Vanuatu provide information on the government's debt management strategy, either as a stand-alone report or part of the government's budget documentation.

Fiji and PNG have large shares of domestic debt, at 75 percent and 55 percent, respectively, and in Fiji the National Provident Fund holds the majority of it. In Vanuatu, domestic debt has declined to around 15 percent of public debt, but in its debt management strategy the government commits to maintaining a small volume of bonds to ensure that the market is available, if needed.

In 2017, Fiji was the first emerging market country to issue a green bond, a F\$100 million offering in the local market. 


\section{FURTHER DEVELOPMENT}

Given the variation in levels of institutional capacity and financing sources across developing Asia, each economy will need a tailored approach in setting priorities for development. Diagnostic tools and performance assessments, such as the DeMPA, are useful inputs for the authorities to design a capacity-building roadmap, particularly in low- and middle-income economies. Economies that rely mostly on official sources of financing and that are about to embark on domestic financing will need to take significant steps toward building debt management capacity and introducing other new sources of financing, such as the international capital markets.

The COVID-19 pandemic has severely tested the debt management capacity of all economies. The scale of its economic impact is almost unprecedented and the resulting fiscal responses have generated an increase in public debt levels that will be likely to continue for many years. Debt managers have had to move rapidly to support their governments' responses to the crisis, which has affected all aspects of their operation. Careful judgment is required in a challenging market environment, with some economies seeing severe market dislocation and capital flow reversal, particularly in the initial stages of the crisis.

Debt managers need to coordinate closely with fiscal policy decision-makers in order to guide them on the amount of additional financing that can be raised over a specific time frame. In this regard, the original annual borrowing plan (ABP) and probably also the medium-term debt management strategy (DMS) will need to be revised as the original assumptions about financing requirements, costs and sources will probably no longer apply. Central to reworking the DMS is considering the appropriate trade-off between cost and risk under the new circumstances. In some cases, this may require accepting more risk, for example through additional short-term or foreign-currency financing. Debt managers should explain to decision-makers the rationale for such changes to the DMS as it could reduce fiscal flexibility in the future.

Many economies have difficulty executing transactions in markets during periods of crisis, as debt managers have to respond to rapidly changing conditions. In domestic markets, there is greater risk of failing to attract sufficient bids to cover auctions of securities; it is necessary therefore to prepare for this eventuality by managing liquidity buffers, installing backup financing mechanisms, engaging in market communication, adjusting issuance mechanisms such as the frequency and size of auctions, and making greater use of syndication to reduce execution risk. For economies with financing requirements in the international capital markets, access has been restricted, particularly for weaker credits, with investors experiencing periods of risk aversion. Debt managers therefore need to be flexible and capable of obtaining necessary approvals quickly so as to take advantage of favorable opportunities. Some economies have used liability management operations to help stabilize markets, as has been the case in earlier crisis situations.

Debt managers must also coordinate more closely with the monetary authorities. The departure of nonresident investors from the domestic market has implications for the exchange rate and potentially foreign-exchange reserves levels. Similarly, close coordination is required when international bonds are maturing or when there is a change in plans for foreign-currency borrowing. In extreme circumstances it may be legally permissible for the government to draw on an overdraft from the central bank. This is clearly a last resort to be used only when normal financing channels have failed; the protocols for when and how this would be implemented 
should be established as a precautionary measure, in coordination with the government's cash manager. In response to the COVID-19 crisis, some central banks in emerging market economies have launched programs to purchase domestic government securities, including five in developing Asia (Arslan et al. 2020). Unlike in high-income economies, bond purchases did not take place when the policy rate had reached the zero lower bound, but rather to provide liquidity and stabilize bond markets during a period of dysfunctionality.

The nature of the COVID-19 crisis has tested debt management capacity, because of the need for physical distancing and national or city lockdowns. In some cases, staff have been required to work from home and business continuity plans (BCPs) have been activated. The pandemic has amplified the need for heightened awareness of operational risk, particularly when the period of operating under the BCP extends beyond the time anticipated in the plan. In sum, debt managers have faced a perfect storm of elevated financing requirements, market dislocation, emergency operating procedures, and concerns for personal and family health.

At the time of writing, the COVID-19 pandemic and the associated economic crisis is still evolving, pressing for urgency in strengthening debt management capacity, particularly as governments face rising debt burdens that will be likely to stretch to many years. In addition, the lessons learned from earlier crises suggest that actions in two areas in particular can help economies address the challenges and any possible future shocks. The first is improving transparency in debt management, which can pay dividends within a short time. The other area is more of a long-term endeavor: developing the domestic debt market.

\subsection{Improving Transparency}

The need for transparency in managing public debt has long been recognized; one-sixth of the Guidelines for Public Debt Management was devoted to the topic. There are three broad reasons for this. First, the effectiveness of debt management operations can be strengthened if the objectives and the DMS are disclosed, and the authorities can make a credible commitment to meeting them. ${ }^{12}$ Second, disclosure of the regulations and operating procedures for the primary and secondary markets for government securities assures investors that the markets are well managed. Third, disclosure of the stock and composition of public debt, and projected budget needs and financing intentions reduces uncertainty for investors, which improves outcomes for the government.

The value of transparency was confirmed by the economies' experiences during the global financial crisis of 2008-2009. In 2010, debt managers from 33 high-income economies and emerging market economies met to discuss lessons learned from the crisis and agreed on 10 guiding principles (IMF 2010). Half of them relate to transparency and communication.

While there may be a reluctance to announce negative news, there is little to be gained in the long term from withholding or delaying materially important information. Investors and financial intermediaries closely monitor economic and other relevant developments and, in the absence of official announcements, will infer the implications for the level and mix of government financing. There is a risk that their conclusions may be worse than the reality. Debt managers should coordinate closely with the fiscal authorities and provide guidance to markets as soon as is reasonably practicable. There is also some empirical evidence that improving transparency in the provision of data can lower borrowing costs for emerging market economies (IMF 2017a). 
The level and timeliness of disclosures on public debt and its management across economies vary a great deal, as outlined in the section on Debt Management Capacity in Developing Asia. This is an area where there are few exogenous constraints on the authorities; institutional capacity can be built by deciding that transparency is a priority and allocating resources accordingly. While debt managers generate much of the information and data, they must collaborate with the fiscal and political authorities on projections for future borrowing.

Some economies go beyond basic transparency measures by developing an investor relations function, which in practice extends to a range of stakeholders, including rating agencies, financial intermediaries, financial and mainstream media, and the general public. The investor relations program aims, first, to build trust and develop a long-term relationship with investors and other stakeholders by providing relevant data and information and maintaining active dialogue. Second, it seeks to obtain feedback on investors' preferences and how the debt manager could improve performance. These relationships can pay dividends during a crisis and give stakeholders greater confidence in knowing they are receiving accurate and timely information.

The Institute of International Finance (IIF) has developed a framework to assess the quality of investor relations and data dissemination practices of emerging market economies, based on a set of 20 criteria for the evaluation of investor relations practices and a set of 23 criteria for the evaluation of data dissemination practices (IIF 2019). The 2019 assessment covered 38 economies, mostly those that are active in the international capital markets, including eight in developing Asia. ${ }^{13}$ Indonesia had the maximum score for investor relations, together with five economies in other regions; scoring also the highest in Asia for data dissemination practices. The Philippines and Thailand scored strongly for both measures, whereas the PRC and Viet Nam scored the lowest in Asia, with Viet Nam being one of four economies globally with scores in the lowest quartile.

\subsection{Domestic Debt Market Development}

The importance of a domestic debt securities market for the efficient functioning and resilience of the financial system has long been recognized in Asia, as evidenced by the ABMI. The government securities market plays a central role by providing (1) a benchmark yield curve for pricing private sector debt securities and other contracts, such as derivatives; (2) a low-risk and liquid instrument for use as collateral, which underpins the money markets and supports liquidity management operations of the central bank; (3) an investment alternative with little or no risk of default for investors; and (4) impetus to develop market infrastructure (payment and settlement systems) and a strong legal and regulatory framework. As noted earlier, Singapore and Hong Kong, China developed a local government bond market to derive these benefits, even though they had no fiscal need to borrow. Other economies, too, such as Australia and New Zealand, have made commitments to maintain certain minimum volumes of government bonds outstanding in order to support efficient market functioning.

For the government, a well-functioning debt securities market allows financing in local currency and at long tenors, overcoming balance sheet mismatches. ${ }^{14}$ Currency mismatches have played a significant role in most major financial crises that had an impact on emerging market economies since the early 1980s (Committee on the Global Financial System 2007). But the global financial crisis of 2008-2009 was different-major emerging market economies 
withstood severe dislocation in currencies, rates and spreads. In part this was attributed to the significant reduction in the share of external debt in government debt portfolios earlier in the decade, particularly in emerging Europe and Latin America. ${ }^{15}$ Other factors that supported the favorable outcome were improved macroeconomic management and measures to extend the maturity of domestic debt.

The contrasts across developing Asia on the level of domestic market development could not be more extreme, as discussed earlier: nine economies rely entirely on domestic financing, whereas 13 have no domestic market at all. And the economies in the middle cover the full range - from those just starting on the journey to those with fairly liquid secondary markets. Several enabling conditions shape the potential for market development: macroeconomic performance, scale and structure of the financial sector, and financial sector soundness. For example, high and volatile inflation, high levels of dollarization, high risk of debt distress, or little need by the government to source market financing would inhibit the emergence of a market. Similarly, financial repression, a limited domestic savings base, or an unsound banking sector would militate against a viable market.

The framework for developing local-currency bond markets has been well understood for many years and can be summarized as comprising six building blocks: ${ }^{16}$

1. Money market: A reliable short-term money market yield curve supports the pricing of longer maturities, and government securities underpin the repo markets. The precondition for a well-functioning money market is a liquid and efficient interbank market.

2. Primary market: The choices made by government debt managers will shape the maturity structure and strongly influence the liquidity of the market.

3. Investor base: A well-diversified investor base ensures demand for government securities at a range of tenors and under varying market conditions; it also supports liquidity.

4. Secondary market: A liquid secondary market provides near-continuous pricing that guides yields at which the government and other issuers can sell in the primary market.

5. Financial market infrastructure: This includes payment, settlement, and custody systems that support safe, cost-effective and convenient transacting.

6. Legal and regulatory framework: Investors require assurance that the legal and regulatory framework provides sound underpinnings for the operation of the market.

As can be seen, the process of developing a government securities market is complex and involves a broad range of elements and numerous interactions, requiring a collaborative effort with the public debt manager, the regulator, the central bank, and market participants. Economies in developing Asia with no, or with a limited volume of, domestic government securities should consider the enabling conditions carefully. The easing of any constraints in this regard is an important first step and will strongly influence the pace and shape of development to follow.

For the many economies in the middle, the development process can be informed by the "building block" approach, and the IMF and the World Bank are creating indicators to measure the level of development for each (IMF and the World Bank 2020). In addition, there is a wealth of economy experiences that can be tapped in Asia, as well as globally, that can provide guidance on tackling common issues across economies.

Even the high-income economies and others that rely on the domestic market need continuous improvement, as is the case in OECD economies. There is always scope for improving 
market efficiency and resiliency in the context of a changing landscape, including technology, shifts in the investor base, evolution of the dealer community, regulatory developments, and introduction of new instruments.

\section{NEW OPPORTUNITIES AND CHALLENGES}

Institutional capacity to manage public debt needs to keep pace with new opportunities in markets, such as the rise of environmental, social and governance (ESG) investing. It can also be adapted to support governments' efforts to manage fiscal risk, and three areas are outlined in this section: (1) a holistic approach by managing risk in an asset-liability management framework; (2) explicit contingent liabilities; and (3) risk transfer using market instruments.

\subsection{Environmental, Social, and Governance}

The instruments available to public debt managers continue to expand: Islamic finance has grown rapidly in the last 20 years, with Malaysia an early adopter and a significant issuer. Singapore was the first non-Muslim majority country to issue sukuk in 2009. More recently, governments have starting tapping the ESG investing market. Each innovation requires the development of institutional capacity, as these markets impose greater requirements than those when issuing conventional bonds.

Bond markets have seen increasing interest in ESG investing, particularly in green bonds, as described in Chapter 16 in this volume. This has created opportunities for borrowers to broaden and diversify their investor bases, including governments. In 2017, Fiji was the first developing economy in the world to issue a green bond, and other government issuers in the region include Indonesia; Hong Kong, China; and the ROK.

Issuing in the ESG market requires an expanded debt management capacity, as there are extra steps compared with using the conventional bond market, as fully set out in Chapter 16. The main distinguishing feature of ESG securities is that the proceeds must be allocated to expenditures or investments that are eligible, as defined by global standards. This requires the government debt manager to work with line ministries to identify eligible expenditures and develop a framework to ensure that the allocation process can be monitored and reported, in order to provide accountability to investors. Furthermore, an independent entity must be engaged to provide assurance that the bond issue and framework meet relevant standards. For a first-time issuer the process could be expected to take at least six months.

\subsection{Fiscal Risks}

\section{Sovereign asset-liability management}

Sovereign asset-liability management (SALM) draws insights from the ALM practices of financial institutions, which analyze and manage mismatches between the cash flow of assets and liabilities. In this way, exposure to currency, interest-rate, and liquidity risks can be controlled in line with their business objectives and risk tolerance. The concept has extended to the public sector with similar objectives, and a joint analysis of risks in liability and financial asset portfolios can have advantages over separate management (Das et al. 2012; and Irwin and Parkyn 2009). ${ }^{17}$ It allows the identification of opportunities to create hedges across public 
debt and asset portfolios, that is, adjusting portfolio composition to reduce risk at an aggregate level. Or, natural hedges may be identified, which could reduce the need for managers of individual portfolios to lay off risks in financial markets.

However, implementing SALM in practice is challenging for two broad reasons. First, unlike a financial institution, many sovereign assets are nonfinancial in nature (such as land, buildings and infrastructure). For most sovereigns this means that there is a net financial liability, that is, liabilities exceed the financial assets, so there are limits on the extent to which conventional ALM can be applied. In response, some practitioners and academics have expanded the boundary of SALM to include fiscal flows, recognizing that the government's revenues are primarily taxes, which do not have a direct financial relationship with the government's fixed assets. ${ }^{18}$

The objective of this expanded analysis is to identify a public debt (or net debt) portfolio that "hedges" the primary balance over time. Founded on the economic theory of tax smoothing, it argues that governments should aim to smooth tax rates over time to reduce deadweight losses. ${ }^{19}$ If public debt can be structured such that debt-servicing costs co-vary with the primary balance, it would reduce the need to adjust tax rates. A useful instrument to achieve this outcome would be a GDP-linked security, where the government would pay a higher rate of interest when GDP growth is strong and tax revenues are buoyant (and vice versa). The case for GDP-linked bonds, and other state-contingent instruments, has been argued for some time. ${ }^{20}$ However, in practice their use has been confined largely to sovereign debt restructuring. Some of the reasons for the lack of uptake are lags and revisions in GDP data; a high liquidity premium demanded by investors in the early stage of market development; adverse selection and moral hazard risks; pro-cyclical investor demand; migration of excessive risk to the private sector; and adverse political economy incentives (IMF 2017b).

Instead, governments have analyzed combinations of available instruments that would provide some countercyclicality to the primary balance; and the use of inflation-indexed instruments has increased in recent years, in part due to this property. Other state-contingent instruments, such as those with payouts related to commodity prices, have also seen interest, as discussed in the section, Transfer of risk to markets. In practice this analysis is complex and sensitive to the assumptions made, but it has helped shape portfolio choices in several economies.

A second challenge for SALM is that public sector assets and liabilities are managed by various entities, such as the finance ministry, the central bank, state-owned enterprises, and financial institutions. These entities have a range of governance arrangements, and many enjoy statutory or policy independence-with good reason.

Typically, no entity is assigned the responsibility of overall financial risk analysis - each entity operates separately. Amante et al. (2019) find that in cases where SALM has been successfully implemented, there has been negotiation and a "meeting of minds" between officials in finance ministries and central banks. They characterize SALM principles as being implemented in four situations:

1. Coordinated management of foreign-currency reserves with foreign-currency debt. This is based on the portion of the reserves that is regarded as stable through time (examples: Canada, Denmark, Hungary, New Zealand, Turkey, Sweden, and the United Kingdom). 
2. Managing asset levels to cover maturing liabilities during adverse market conditions. This supports the management of liquidity risk (examples: Denmark, New Zealand, South Africa, Turkey, and Uruguay).

3. Transactions between the central bank and government that strengthen policy outcomes, reduce cost and reduce risk. This is usually addressing a sizable build-up of liabilities on a central bank balance sheet, such as sterilizing the buildup of foreign-currency reserves during periods of strong capital inflows (examples: Brazil, Mexico, Uruguay, and the Russian Federation).

4. Analyzing the variables that drive government revenues as an input to developing debt management strategies. Based on the economic theory of tax smoothing.

The debt management entity manages the largest financial position-central government debt - and with its skills in financial risk management, it is well placed to take a leadership or coordinating role in analyzing risk across the sovereign balance sheet. Nevertheless, this has implications for institutional capacity, including resources, skill sets, and coordination mechanisms. In Uruguay, this grew organically from a network of officials and then was formalized with a high-level coordinating committee, with broad terms of reference (Amante et al. 2019). Within the Asian region, the Ministry of Finance of Indonesia has analyzed financial risk across the public sector balance sheet for a number of years. A sub-directorate within the Directorate General of Budget Financing and Risk Management was established to focus on this task (see Box 14.2).

\section{BOX 14.2 SOVEREIGN ASSET-LIABILITY MANAGEMENT IN INDONESIA}

The Ministry of Finance of Indonesia began analyzing financial risk across the public sector balance sheet in the late 2000 s, initially focusing on the balance sheets of the central government and the central bank. In 2015, it established a sub-directorate within the Directorate General of Budget Financing and Risk Management to focus on sovereign asset-liability management (SALM).

In November 2019, it published on the ministry website an analysis of three risks (currency, liquidity and solvency) for the central government, the Bank Indonesia (the central bank), and seven major state-owned enterprises from 2011 to 2018. The analysis showed that while foreign-currency liabilities were over $\$ 150$ million equivalent by the end of the period, the foreign-currency assets (mostly reserves) offset much of this exposure: the net liability ranged from around $\$ 7$ billion to $\$ 35$ billion over the period. Therefore, the exposure of the public sector balance sheet to changes in the value of the Indonesian rupiah was much less than public sector debt figures would suggest.

The data on exposure to currency risk were complemented by a sensitivity analysis, based on a depreciation of the rupiah of 10 percent and 40 percent, which showed the potential impact on net worth. Given the magnitude of net worth, the risk was viewed as manageable. (Information on the exact composition of foreign-currency reserves was limited, but two scenarios were tested.)

The presentation also provided details of how the consolidated balance sheet was constructed, that is, the cross-holdings between entities that needed to be eliminated. 
The Ministry of Finance intends to expand the coverage of entities in the analysis and continues to refine the methodology.

Source: Directorate of State Financial Risk Management. 2019. Sovereign Asset Liability Management. https:// www.djppr.kemenkeu.go.id/page/load/2677 (accessed 16 September 2020).

\section{Contingent liabilities}

Contingent liabilities may be explicit, that is, the government has entered into a contract to provide support in certain circumstances, such as guarantees, or they may be implicit in nature. Chapter 11 in this volume describes contingent liabilities in detail, as well as their use in Asia.

Given the potential impact of explicit contingent liabilities on public finances, governments require effective institutional capacity to use them as a policy instrument, including a framework that controls their use, for example the circumstances in which they will be utilized and limits on the volumes of guarantees that may be granted. Effective processes need to be established to ensure that individual contracts conform to the policy framework and are recorded and reported appropriately. With procedures in place and a control environment to manage processes and operational risk, the government debt manager is well placed to perform some of these functions.

The OECD's survey of 33 economies revealed that the debt managers' extent of involvement in this area varies widely across economies, as well as by type of contingent liability. ${ }^{21}$ In two-thirds of the economies, they had a role in the management of contingent liabilities, largely credit guarantees (contracts where the government assumes all or part of the credit risk of a loan extended to another party). The predominant function performed was monitoring and reporting guarantees; around half also calculated the expected cost, that is, an analysis of the probability of the guarantee being called and, if so, the probable size of the payment. The survey also showed that debt managers had comparatively little involvement in the management of other contingent liabilities that were considered, such as public-private partnership guarantees, program loan guarantees (e.g., for students or housing), and government insurance schemes.

If the debt manager were assigned to manage contingent liabilities, capacity building would probably be required. While the management of currency, interest-rate and liquidity risks is a core responsibility of the debt manager, usually managing credit risk is not. Assessment of credit risk may be required as part of the decision-making process for granting a guarantee; governments that perform this analysis use a number of techniques, as described in Bachmair (2016). It may also be assessed on an ongoing basis as part of monitoring a portfolio of credit guarantees.

\section{Transfer of risk to markets}

It is possible to transfer some fiscal risks to the insurance or capital markets, for example, exposure to commodity price risk and natural hazards. A number of economies have managed risk in this way, as described in Chapter 15 in this volume. This requires government to use financial instruments or structures that may not be part of the existing debt management toolkit, such as swaps, options, reinsurance contracts and catastrophe bonds.

This chapter identifies a number of challenges to the use of these tools, including gaps in the legal framework and clear institutional responsibility for identifying and measuring the risks, 
as well as deploying solutions to mitigate them. The public debt management entity would be a logical candidate to perform this role, particularly as tools are typically based in the global capital markets. Nevertheless, significant capacity building would be required to analyze new types of risk and to put in place the enabling environment to transact, including laws, derivatives agreements, risk management framework, and skill sets.

\section{CONCLUSION}

Poorly managed public debt portfolios can contribute to debt sustainability problems by allowing the build-up of financial risk, such as currency and interest-rate risks, which can threaten the health of public finances as a crisis looms.

Effective debt management capacity is therefore one pillar supporting sustainable public debt levels. However, it is not a guarantee of sustainability - it is possible for a government to have a well-managed and low-risk debt portfolio but face sustainability concerns because of too much debt. Fiscal institutions need to be effective, too.

Many of the 46 developing Asian economies have invested significantly in debt management capacity in recent decades, placing them in a good position to weather the COVID-19 crisis. At one end of the spectrum are those that rely mostly on domestic debt markets to finance government, which increases resilience in turbulent times such as these. At the other end are those that rely on financing from official sources, which highlights the need for an effective international response.

Given these divergent positions, and the diversity of circumstances in between, there are no universal prescriptions on actions needed to strengthen capacity. Each economy requires its own roadmap, and this chapter provides color on the types of challenges they face. Nevertheless, the lessons learned from earlier crises suggest that actions in two areas in particular can help economies deal with this event and shocks that may come in the future. One is to improve transparency about public debt and its management, which can be carried out in the short run. The other is developing the domestic debt market, which has a longer time frame.

There are new opportunities for governments in the borrowing arena and to manage fiscal risks more effectively. This chapter identifies innovations and possibilities in four areas: (1) ESG investing; (2) sovereign asset-liability management; (3) management of explicit contingent liabilities; and (4) transferring risks arising from commodity prices and disasters triggered by natural hazards to markets. While these offer opportunities to reduce costs, increase returns, and reduce risk, investment in institutional capacity is usually required. In some of these areas the case can be made that building that capacity in the public debt management function is an efficient solution, as it has a strong base in risk analysis, transaction execution, and management of operational risk.

\section{NOTES}

1. The views expressed therein are those of the authors and do not necessarily reflect the views and policies of ADB, its Board of Governors or the governments they represent.

2. International Monetary Fund (IMF) and the World Bank (2014). The original and revised guidelines were based on wide consultation with public debt managers in economies of all income levels.

3. World Bank (2015). This is a revision of the original, which was finalized in 2009.

4. "Small states" were defined in the study as having a population of less than 2 million. The sample included Samoa, Solomon Islands, Maldives, and Bhutan. 
5. In this chapter, data for Afghanistan were valid as of 14 December 2020 and may have changed thereafter because of major recent events affecting the country.

6. At least one activity; in some economies there were more (World Bank 2020; ADB 2018).

7. The economies in the initiative are the members of the ASEAN, the PRC, Japan, and the ROKcollectively known as ASEAN +3 .

8. Detailed guides on the structure of each market and descriptions of the development process can be found on the ABMI website: https://asianbondsonline.adb.org/abmg.php.

9. India plans to set up a public debt management agency and has been strengthening the capacity of the Ministry of Finance as an interim step.

10. There is no available information on Turkmenistan.

11. In this chapter, data for Myanmar were valid as of 14 December 2020 and may have changed thereafter because of major recent events affecting the country.

12. The same thinking applies to transparency in fiscal and monetary policies. See IMF $(1999 ; 2007)$.

13. The PRC, Indonesia, the ROK, Malaysia, Pakistan, the Philippines, Thailand, and Viet Nam.

14. For example, see Eichengreen and Hausmann (1999) who used the term "original sin" to describe the situation where debt managers had to choose between two types of risky borrowing: at long-term maturities, but in foreign currencies; or in domestic currency but at very short-term maturities.

15. Anderson et al. (2010). The authors analyzed the largest 24 emerging market economies, and the average level of external debt fell from 75 percent to 22 percent of total public debt between 2000 and 2009.

16. See IMF and the World Bank (2001) and IMF and the World Bank (2020).

17. The term "sovereign" refers to the public sector including the central government, state-owned enterprises, the central bank, pension funds, and other entities over which the government has financial control.

18. See for example Wheeler (2004) and IMF (2018). The combined accounting and fiscal balance sheet has been named "comprehensive" or "inter-temporal".

19. See Bohn (1990) and Barro (1995).

20. For example, Borensztein and Mauro (2004) and Benford et al. (2018).

21. Ulgenturk (2017). The survey was undertaken in 2013.

\section{REFERENCES}

Amante, A., P. Anderson, T. Jonasson, H. Kamil and M. Papaioannou. 2019. Sovereign Asset and Liability Management in Emerging Market Countries: The Case of Uruguay. IMF Working Paper. WP/19/290. Washington, DC: IMF.

Anderson, P.R.D., A.C. Silva and A. Velandia-Rubiano. 2010. Public Debt Management in Emerging Market Economies: Has this Time been Different? Policy Research Working Paper. 5399. Washington, DC: World Bank.

Arslan, Y., M. Drehmann and B. Hofmann. 2020. Central Bank Bond Purchases in Emerging Market Economies. BIS Bulletin No. 20. Basel: Bank for International Settlements.

Asian Development Bank (ADB). 2017. The Asian Bond Markets Initiative: Policy Maker Achievements and Challenges. Manila.

Asian Development Bank (ADB). 2018. Strengthening Public Debt Management through Policy-Based Operations. Pacific Economic Monitor. December. https://www.adb.org/sites/default/files/publication/ 471196/pem-december-2018.pdf (accessed 20 September 2020).

Asian Development Bank (ADB). 2019. Good Practices for Developing a Local Currency Bond Market: Lessons from the ASEAN+3 Asian Bond Markets Initiative. Manila.

Bachmair, F.F. 2016. Contingent Liabilities Risk Management: A Credit Risk Analysis Framework for Sovereign Guarantees and On-Lending. Country Experiences from Colombia, Indonesia, Sweden, and Turkey. Policy Research Working Paper. 7538. Washington, DC: World Bank.

Barro, R.J. 1995. Optimal Debt Management. NBER Working Papers. 5327. Cambridge, MA: National Bureau of Economic Research. 
Benford, J., J.D. Ostry and R. Shiller (eds). 2018. Sovereign GDP-Linked Bonds: Rationale and Design. London: CEPR Press.

Bohn, H. 1990. Tax Smoothing with Financial Instruments. The American Economic Review. 8(5), pp. 1217-30.

Borensztein, E. and P. Mauro. 2004. The Case for GDP-Indexed Bonds. Economic Policy. 19(38), pp. 166-216.

Committee on the Global Financial System. 2007. Financial Stability and Local Currency Bond Markets. CGFS Papers. No. 28. Basel: Bank for International Settlements.

Das, U.S., Y. Lu, M.G. Papaioannou and I. Petrova. 2012. Sovereign Risk and Asset and Liability Management: Conceptual Issues. IMF Working Paper. WP/12/241. Washington, DC: IMF.

Eichengreen, B. and R. Hausmann. 1999. Exchange Rates and Financial Fragility. NBER Working Paper. No. 7418 (November).

Institute of International Finance (IIF). 2019. Principles for Stable Capital Flows and Fair Debt Restructuring: Report on Implementation by the Principles Consultative Group. https://www.iif.com/ Publications/ID/3608/2019-PCG-Report-on-Implementation-of-the-Principles (accessed 2 September 2020).

International Monetary Fund (IMF). 1999. Code of Good Practices on Transparency in Monetary and Financial Policies: Declaration of Principles. Washington, DC.

International Monetary Fund (IMF). 2007. Code of Good Practices on Fiscal Transparency. Washington, DC.

International Monetary Fund (IMF). 2010. Stockholm Principles: Guiding Principles for Managing Sovereign Risk and High Levels of Public Debt. https://www.imf.org/external $/ \mathrm{np} / \mathrm{mcm} / \mathrm{Stockholm} /$ principles.htm (accessed 26 September 2020).

International Monetary Fund (IMF). 2017a. The Effects of Data Transparency Policy Reforms on Emerging Market Sovereign Bond Spreads. IMF Working Paper. WP/17/74. Washington, DC.

International Monetary Fund (IMF). 2017b. State-Contingent Debt Instruments for Sovereigns. IMF Policy Paper. May 2017. Washington, DC.

International Monetary Fund (IMF). 2018. Managing Public Wealth, World Economic and Financial Surveys. Fiscal Monitor. October. Washington, DC.

IMF and the World Bank. 2001. Developing Government Bond Markets: A Handbook. Washington, DC.

IMF and the World Bank. 2014. Revised Guidelines for Public Debt Management. Washington, DC.

IMF and the World Bank. 2019. Uzbekistan: Developing a Medium-Term Debt Management Strategy. https://www.mf.uz/media/file_en/debt/MTDS_report_17_10_2019.pdf (accessed 24 September 2020).

IMF and the World Bank. 2020. Recent Developments on Local Currency Bond Markets in Emerging Economies. Staff Note for the G20 International Financial Architecture Working Group (IFAWG). http://documents1.worldbank.org/curated/en/129961580334830825/pdf/Staff-Note-for-the-G20 -International-Financial-Architecture-Working-Group-IFAWG-Recent-Developments-On-Local -Currency-Bond-Markets-In-Emerging-Economies.pdf (accessed 25 September 2020).

Irwin, T. and O. Parkyn. 2009. Improving the Management of the Crown's Exposure to Risk. Treasury Working Paper Series. 09/06. Wellington, New Zealand.

Pacific Association of Supreme Audit Institutions (PASAI). 2016. Pacific Regional Report on Public Debt Management. Auckland, New Zealand. https://static1.squarespace.com/static/57019a6db6aa607 cbb909ab2/t/5806f43b20099eaea984c1 fb/1476850777461/PASAI+Public+debt+report+19+OCT+ 2016_WEB.pdf (accessed 21 September 2020).

Prasad, A., M. Pollock and Y. Li. 2013. Small States Performance in Public Debt Management. Policy Research Working Paper. WPS6356. Washington, DC: World Bank.

Ulgenturk, L. 2017. The Role of Public Debt Managers in Contingent Liability Management. OECD Working Papers on Sovereign Borrowing and Public Debt Management. No. 8. Paris: OECD Publishing.

Wheeler, G. 2004. Sound Practice in Government Debt Management. Washington, DC: World Bank. 
World Bank. 2015. Debt Management Performance Assessment (DeMPA) Methodology. Washington, DC.

WorldBank. 2019. Maldives-DebtManagementPerformance Assessment(DeMPA).Washington,DC.https:// documents.worldbank.org/en/publication/documents-reports/documentdetail/964251564149648484/ maldives-debt-management-performance-assessment-dempa (accessed 25 September).

World Bank. 2020. Debt Management Monitor: DMF Country Profiles and Debt Management Technical Assistance. Issue 5. May. Washington, DC.

World Bank and the IMF. 2018. G-20 Note: Improving Public Debt Recording, Monitoring, and Reporting Capacity in Low and Lower Middle-Income Countries: Proposed Reforms. Washington, DC. 